\title{
The Effect of Cooperative Learning Model Type Numbered Heads Together (NHT) Assisted Media Video and Motivation on Natural Science Achievement of Elementary School Students
}

\author{
Iqbal \\ Basic Education \\ Postgraduate Universitas Negeri Medan \\ Medan, Indonesia \\ Corresponding email: iqbalpersist012@gmail.com \\ Sahyar \\ Postgraduate Universitas Negeri Medan \\ Medan, Indonesia \\ Ajat Sudrajat \\ Postgraduate Universitas Negeri Medan \\ Medan, Indonesia
}

\begin{abstract}
Numbered Heads Together (NHT) model used a series of delivery of materials by using groups as a container in unifying students perceptions/ minds to questions asked or asked teachers, which will then be accountable by students in accordance with the teachers request number each group. This research aimed to know: the effect of cooperative learning model type NHT assisted video media on students natural science achievement; the effect of motivation students natural science achievement and interaction between learning model and motivation in increasing students natural science achievement. This research was a quasiexperimental research. Instruments in this research were objective test of natural science and questionnaire motivation in learning. Data analysis technique used was two-way Analysis of Variance at significant level alpha 0.05 . The results of this research showed that: there was an effect of cooperative learning model type NHT assisted video media on students natural science achievement, with value of significant 0.000 ; there was effect of motivation on students natural science achievement, with value of significant 0,000 and there was an interaction between learning model and motivation in increasing students natural science achievement with value of significant 0.031 .
\end{abstract}

Keywords-Cooperative learning model; motivation; natural science achievement

\section{INTRODUCTION}

Basically Natural Science is a way of finding out about nature systematically to master the collection of knowledge in the form of facts, concepts, principles, process of discovery and have a scientific attitude. Science and science lesson are not just scientific knowledge, but there are a charge of natural science, process skills and dimensions that focus on the characteristics of scientific attitude and character.

Various problems in the implementation of science education in accordance with the nature is very complex, because the thoughts are still being donated to solve the problem. The fundamental problem is that science learning has not been oriented to the skills of the whole scientific process so that the ability to think and investigation ability has not been optimal. The consequences of such learning products are the decreasing ability of critical and creative thinking. This will shape the consumerist generation and not globally competitive.

Based on observations the researcher did on August 30 and September 01 in public elementary school 060856 Medan in natural science, it appeared that the application of various models of cooperative learning has not been done, teachers tend to used conventional method that was by way of lectures so that the student activity was less active and this condition were seen many students are passive and did the excercises that are in the book. Beside that, the students are less motivated in following the lesson so the students' curiosity was low on the material being taught.

In accordance with the reality in the field, the low learning outcomes of students in elementary school 060856 Medan, also against the lack of involvement of students in the learning process. This was influenced by internal and external factors. In addition, one of the factors causing low learning outcomes of students in science subjects was the method of teaching and 
motivation given by the teacher to students less relevant with the characteristics of students. Teachers also lack emphasis on students to reason, to find the relevance of subject matter, communicate, and solve problems, so there were no time for students to develop effective learning strategies. This was evident from the results of the average score of natural science students during the last three years in grade five in public elementary school 060856 Medan was still under minimum completeness criteria. Terms completeness minimum completeness criteria in public elementary school 060856 the terrain is seventy. This proves that the value of students were still low. Therefore, to be able to develop or improve students' skills both in understanding and motivation to learn, and reduce the passivity of students in science learning, so that teachers need to use variations of learning models that can involve students actively in the learning process. One way that can actively involve students and to improve student learning outcomes is the cooperative learning model type NHT. The cooperative learning model type NHT is a series of delivery of materials by using groups as a container in unifying students' perceptions thoughts on questions asked or asked by teachers, which will then be accountable by students according to teachers request number from each group [1]. The cooperative learning model type NHT provides an opportunity for students to share ideas and consider the most appropriate answer [2]. In addition, this technique also encourages students to improve their morale of cooperation and this model of learning is more emphasis on student activity in searching, processing and reporting information from various sources that eventually presented in front of the class.

To avoid the boredom of students in learning and enthusiastic in following the lesson, then the teacher needs to use the learning media in teaching and learning process. One of the learning media is video media. The video describes the real state of a process, phenomenon or event so as to enrich the exposure [3]. The video capability of painting live and sound images provides its own charm. Videos can present information, describe processes, explain complex concepts, teach skills, abbreviate or prolong the time, and influence attitudes.

From the above description, the researcher was interested to further research under the title " The Effect of Cooperative Learning Model Type Numbered Heads Together (NHT) Assisted Media Video and Motivation on Natural Science Achievement of Elementary School Student".

This research aimed to know: the effect of cooperative learning model type NHT assisted video media on students natural science achievement; the effect of motivation students natural science achievement and interaction between learning model and motivation in increasing students natural science achievement.

\section{METHOD}

This research was conducted at public elementary school 060856 Medan, which was located at Rakyat street, Number 30, District of Medan Perjuangan. The population of this study were all students of class V public elementary school 060856 Medan, which consists of two classes, namely grade five-A, and grade five-B, amounting to 60 people. The sample in this research was grade five-A, and grade five-B. Sampling technique in this research used Total Sampling. Grade five-B as an experimental class taught by cooperative learning model type Numbered Heads Together (NHT) assisted media video with the number of students 30 people. As for the control class was taught with Direct Instruction (DI) assisted media picture selected grade five-A with the number of students as many as 30 people.

The independent variable in this research was cooperative learning model type NHT assisted media video and model DI assisted media picture. The moderator variable used was the motivation in learning which was distinguished between high motivation and low motivation. While the dependent variable in this student achievement of natural science.

This research used quasi experiment method. In this research, the effect of treatment was analyzed by $2 \times 2$ factorial design with 2 lane variance analysis (ANAVA) technique, as in the table below.

TABLE 1. ANOVA RESEARCH DESIGN 2 X 2

\begin{tabular}{|c|c|c|c|}
\hline \multirow{2}{*}{$\begin{array}{l}\text { Motivation in } \\
\text { Learning } \\
\text { (B) }\end{array}$} & \multicolumn{2}{|c|}{ Learning Model (A) } & \multirow[t]{2}{*}{ Average } \\
\hline & $\begin{array}{c}\text { DI } \\
\text { Assisted Media } \\
\text { Picture }\left(\mathrm{A}_{1}\right) \\
\end{array}$ & $\begin{array}{c}\text { NHT } \\
\text { Assisted Media } \\
\text { Video }\left(\mathrm{A}_{2}\right) \\
\end{array}$ & \\
\hline High $\left(B_{1}\right)$ & $\mathrm{A}_{1} \mathrm{~B}_{1}$ & $\mathrm{~A}_{2} \mathrm{~B}_{1}$ & $\mu \mathrm{B}_{1}$ \\
\hline Low $\left(B_{2}\right)$ & $\mathrm{A}_{1} \mathrm{~B}_{2}$ & $\mathrm{~A}_{2} \mathrm{~B}_{2}$ & $\mu \mathrm{B}_{2}$ \\
\hline Average & $\mu \mathrm{A}_{1}$ & $\mu \mathrm{A}_{2}$ & \\
\hline
\end{tabular}

The hypothesis of this research was there was effect of cooperative learning model type NHT assisted video media on student achievement of natural science, there was effect of motivation in learning on student achievement of natural science, there was an interaction between learning model and motivation in learning on students achievement of natural science.

Hypothesis tested of this research was conducted by used two-way Variance Analysis (ANAVA) at significance level $\alpha$ $=0.05$ used univariate General Linear Model (GLM) test with SPSS version 22 for windows.

\section{RESULT}

The results obtained in this study include learning scores and questionnaires of students' motivation in learning in the experimental class taught by cooperative learning model type NHT assisted video media and in control class with model DI assisted media picture Natural Events Disaster materials. 
TABLE 2. PRETES AND POSTES STUDENT LEARNING RESULTS

\begin{tabular}{|c|c|c|c|}
\hline Class & $\mathrm{N}$ & Average & Average \\
\hline Experiment & 30 & 44.40 & 82.00 \\
\hline Control & 30 & 42.67 & 72.27 \\
\hline
\end{tabular}

Table 2 above, showed that the average pretest of students learning outcomes of both classes has the same initial ability. From the mean data of the students postes in the second grade of the class showed that there were data of student learning result that was taught with cooperative learning model type NHT assisted media video was higher than the mean of students achievement which was taught by model DI assisted media picture.

Terms of data analysis with parametric statistics was assumption test or prerequisite. In order for later data of research result can be analyzed with parametrik statistic, so need to do normality test and homogeneity test. .

\section{TABLE 3. NORMALITY AND HOMOGENEITY PRETEST DATA}

\begin{tabular}{|c|c|c|c|c|c|c|}
\hline \multirow{2}{*}{ Class } & \multirow{2}{*}{$\mathrm{N}$} & \multicolumn{3}{|c|}{ Kolmogorov-Smirnov ${ }^{\mathrm{a}}$} & \multicolumn{2}{c|}{ Levene } \\
\cline { 3 - 5 } & & Statistic & df & Sig. & $\mathrm{F}$ & Sig. \\
\hline Experiment & 32 & 0.118 & 30 & 0.200 & 0.126 & 0.724 \\
\hline Control & 30 & 0.135 & 30 & 0.172 & & \\
\hline
\end{tabular}

Based on the normality of pretest data in Table 3, significant value in Kolmogorov-Smirnov was greater than 0.05 in the experimental and control classes. This result indicated that data in both classes was normal. Then the homogeneity of pretest data showed significant value greater than 0.05 , so the two classes was homogeneous.

TABLE 4. NORMALITY AND HOMOGENEITY DATA POSTES

\begin{tabular}{|c|c|c|c|c|c|c|}
\hline \multirow{2}{*}{ Class } & \multirow{2}{*}{$\mathrm{N}$} & \multicolumn{3}{|c|}{ Kolmogorov-Smirnov $^{\mathrm{a}}$} & \multicolumn{2}{c|}{ Levene } \\
\cline { 3 - 6 } & & Statistic & $\mathrm{df}$ & Sig. & $\mathrm{F}$ & Sig. \\
\hline Experiment & 32 & 0.134 & 30 & 0182 & 2.556 & 0.115 \\
\hline Control & 30 & 0.091 & 30 & 0.200 & & \\
\hline
\end{tabular}

Based on the normality of postes data in Table 4, significant values in Kolmogorov-Smirnov were greater than 0.05 in the experimental and control classes. These results indicated that data in both classes was normal. Then the homogeneity of pretest data showed significant value greater than 0.05 , so the two classes was homogeneous.

Based on the data division of high motivation groups and low motivation, then the data of student achievement was grouped accorded to the motivation data. Grouping was done based on the ideal score of motivation of all students. The purpose of grouped were to see student achievement that have high motivation and low motivation.
TABLE 5. GROUP POSTES VALUE OF STUDENTS BASED ON MOTIVATION LEVEL

\begin{tabular}{|c|c|c|}
\hline Group & N & Average \\
\hline High Motivation & 41 & 84.46 \\
\hline Low Motivation & 19 & 67.79 \\
\hline
\end{tabular}

Based on table 5 above, it can was explained that the average student achievement who have high motivation higher than the average results of students who have low motivation.

TABLE 6. STUDENT POSTES VALUE BASED ON MOTIVATION LEVEL IN EXPERIMENT CLASS (NHT)

\begin{tabular}{|c|c|c|}
\hline Group & N & Average \\
\hline High Motivation & 19 & 86.11 \\
\hline Low Motivation & 11 & 74.91 \\
\hline
\end{tabular}

TABLE 7. STUDENT POSTES VALUE BASED ON MOTIVATION LEVEL ON CONTROL CLASS (DI)

\begin{tabular}{|c|l|l|}
\hline Group & $\mathrm{N}$ & Average \\
\hline High Motivation & 22 & 77.45 \\
\hline Low Motivation & 8 & 58.00 \\
\hline
\end{tabular}

Based on table 6 and table 7 above, it can was explained that the average of student achievement in the NHT class with the help of video media was higher than the class of DI assisted picture media both in high and low motivation categories.

After the data collected and analyzed statistics, then performed hypothesis tested. This hypothesis test used twotrack ANAVA test which calculated by SPSS 22 for windows. From the test data obtained learning results, calculated the average of each group and then compiled as two-lane ANAVA table.

TABLE 8. ANAVA 2 X 2

\begin{tabular}{|l|c|c|c|}
\hline \multirow{2}{*}{ Motivation } & \multicolumn{2}{|c|}{ Average Learning Outcomes } & \multirow{2}{*}{ Average } \\
\cline { 2 - 3 } & $\begin{array}{c}\text { DI } \\
\text { (Picture Media) }\end{array}$ & $\begin{array}{c}\text { NHT } \\
\text { (Media Video) }\end{array}$ & \\
\hline High & 77,45 & 86,11 & 81,46 \\
\hline Low & 58,00 & 74,91 & 67,79 \\
\hline Average & 72.27 & 82.00 & \multicolumn{2}{|c}{} \\
\hline
\end{tabular}

To see the difference of motivation and student achievement to the learning given, two way Anova test is used by selecting General Linear Model (GLM) univariate on SPSS 22. This test also aimed to see how the influenced of motivation on student achievement, whether students with high motivation have high learning outcomes or vice versa, and whether there was interaction between learning model and motivation in influenced student achievement. 


\section{TABLE 9. TWO PATH LINES ANAVA TEST RESULTS}

\begin{tabular}{|l|r|c|c|c|c|}
\hline \multicolumn{1}{|c|}{ Source } & $\begin{array}{c}\text { Type III Sum } \\
\text { of Squares }\end{array}$ & df & $\begin{array}{c}\text { Mean } \\
\text { Square }\end{array}$ & \multicolumn{1}{c|}{ F } & \multicolumn{1}{c|}{ Sig. } \\
\hline Learning model & 2080,617 & 1 & 2080,617 & 46,678 &, 000 \\
\hline Motivation & 2991,977 & 1 & 2991,977 & 67,124 &, 000 \\
\hline $\begin{array}{l}\text { Learning Model * } \\
\text { Motivation }\end{array}$ & 217,203 & 1 & 217,203 & 4,873 &, 031 \\
\hline Total & & 60 & & & \\
\hline
\end{tabular}

The data in table 9 above, was used to test the hypotheses proposed in this study. The following was a description of the results of the hypothesis test.

\section{First Hypothesis}

Based on the results of Anava in table 9, obtained value of learning model significance of 0.000 because sig. $0.000<0.05$ then the hypothesis tested results rejected $\mathrm{H}_{0}$ or received $\mathrm{H}_{\mathrm{a}}$ in the level of 5\% alpha. This showed that there was an effect of cooperative learning model type NHT assisted video media on students achievement of natural science.

\section{Second Hypothesis}

Based on the results of Anava in table 9, obtained significance value of learning motivation of 0.000 because sig. $0.000<0.05$ then the hypothesis tested results rejected $\mathrm{H}_{0}$ or received $\mathrm{H}_{\mathrm{a}}$ in the level of $5 \%$ alpha. This showed that there was an effect of motivation in learning on students achievement of natural science.

\section{Third Hypothesis}

Based on the results of Anava in table 9, obtained value significance learning model of students motivation in learning of 0.031 because sig. $0.031<0.05$ then the hypothesis tested results reject $\mathrm{H}_{0}$ or receive $\mathrm{H}_{\mathrm{a}}$ in the level of alpha $5 \%$. This showed that there was an interaction between learning model and motivation in learning on students achievement of natural science.

The result of interaction between learning model with motivation in influencing students achievement can be presented in graphic form in picture 1 , below this.

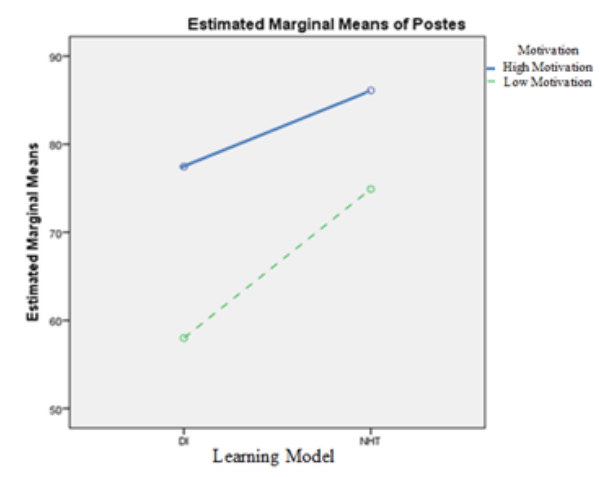

Fig. 1. Interaction chart of DI and NHT learning model with motivation
Based on the above graph, can be explained in the class DI motivation was more dominant in influenced the student achievement of natural science, whereas in the NHT class was more dominant model in influenced the student achievement of natural science. Achievement of natural science students was optimal in students who were taught with NHT learning models for high motivation.

\section{DISCUSSION}

Based on the data analysis, the result of the research showed that the students who were taught by cooperative learning model NHT assisted video media get better grade than the students taught by model DI assisted picture media. In addition, the result of variance analysis showed that the significance value of learning model was 0.000 because sig. $0.000<0.05$ then the hypothesis tested results reject $\mathrm{H}_{0}$ or receive $\mathrm{H}_{\mathrm{a}}$ in the level of alpha 5\%. This showed that there was a significant influenced of cooperative learning model of NHT type assisted video media on student achievement of natural science. In the NHT learning model there was a significant increase in learning outcomes in the cognitive, affective and psychomotor fields [4].

In addition to the results of variance analysis, the results of the study can also be seen from the difference in postes average in both classes. The mean postes of the students in the class were taught with model NHT assisted video media of 82.00 while in the model DI assisted picture media was 72.27. From these data indicated that students learning outcomes taught with NHT model assisted video media was higher than mean of student achievement taught with DI model assisted picture media. The NHT model provides students with the opportunity to discover their own knowledge through group discussions and solve problems within the group. The teacher facilitates and guides the students in a quiet and comfortable state [5]. At the time of numbered phases, students were very enthusiastic about learning in groups and used numbers on their heads. Students felt they had more responsibility and had a serious discussion so that group discussion activities run well. Next phase of thinking together, students unite their opinions on the answers to questions contained in the students worksheet. All students were actively involved in conducted group discussions. In the answering phase, students were trained to dare to communicate the results of the discussion so that to enhance their communication skills [6]. The model NHT can help students to come to thinking in problem solving situations and there was an integrated concept understanding through discussion (exchange of information) in the group as well as corrections by other teams when a team did classroom assignments [7]. The numbered phases in the NHT model allowed the students to be ready for lessons, as each student has the same opportunity [8]. The NHT learning process was more capable of generating an interesting learning environment and more interaction within the group during the learning process [9]. The sense of community that was embedded in NHT learning leads the students in each group to feel interdependent with each other, the success of one person is the success of each member of the group [10]. The NHT model can make students active in follow the learning process 
and not afraid to express or ask questions, so that the learning process can work effectively and fun [11].

Based on the results of the study proved that the average student achievement who had high motivation of 81.46 higher than the results of students who had low motivation of 67.79. In addition, the results of variance analysis indicate that the significant value of motivation in learning was 0.000 . Because sig. $0.000<0,05$ then result of hypothesis tested reject $\mathrm{H}_{0}$ or accept $\mathrm{H}_{\mathrm{a}}$ in level of alpha 5\%. This showed that there were differences in natural science student achievement who had high motivation in learning with students who had low motivation in learning. Motivation encourages effort and learning achievement [12]. The existence of a good motivation in learning will showed good results. This showed that there were differences in natural science student achievement who have high motivation in learning with students who have low motivation in learning. Motivation to learn affects the learning activities and student achievement. Students with great motivation will work hard, seem persistent, do not want to give up, and diligently read to improve achievement and solve problems it faces [13]. Learning motivation gives a significant influenced on the improvement of learning achievement. Students who were motivated to learn will always appear active in the class and dare to express their opinions, and were able to respond to the problems it faces [14]. Students have motivation in learning, then the learning achievement will be good (high). Conversely, if students have bad habits in learning, then the learning achievement will be bad (low) [15]. So students who have high motivation in learning will better understand or master the material taught so that the results of learning was better than students who have low motivation in learning.

This study found the students achievement of natural science that varied between the NHT model assisted video media and model DI assisted media picture with high motivation in learning and low motivation in learning. Based on the result of variance analysis showed that the significance value of learning model interaction with student's motivation in learning was 0.031 because sig. $0.031<0.05$ then the hypothesis tested results reject $\mathrm{H}_{0}$ or receive $\mathrm{H}_{\mathrm{a}}$ in the level of alpha 5\%. This showed that there was an interaction between learning model and motivation in learning on students achievement of natural science. The results of this study also provide an illustration that the students achievement who have high motivation to obtain higher students achievement than low motivation students both taught by learning model NHT assisted video media and model DI assisted media picture.

\section{CONCLUSION}

Based on the result of the research, it can be concluded that there was the effect of cooperative learning model type NHT assisted video media on students achievement of natural science. This proved through calculations that showed significant differences on student achievement between students taught with the learning model NHT assisted video media and model DI assisted media picture. There was an effect of motivation in learning on student achievement of natural science. This was evident through the calculation of average student achievement who have high motivation was better than student achievement who have low motivation. There was an interaction between the learning model and the motivation in learning in influenced on student achievement of natural science. In the interaction in class DI motivation more dominant in influenced on student achievement of natural science, whereas the more dominant NHT class model in affected on student achievement of natural science. Achievement of natural science students were optimal in students who were taught with NHT learning models for high motivation.

\section{REFERENCES}

[1] Istarani, "58 innovative learning model,” Medan: Media persada, 2011, pp. 12.

[2] Fathurrohman, "Innovative learning models," Jogjakarta: Ar-ruzz media, 2015 , pp.82.

[3] Hamdani, "Teaching and learning strategies," Bandung: Pustaka setia, 2011, pp.254.

[4] Y. Miaz, "The implementation of numbered heads together to improve the students' achievement of social sciences in primary school," Research Journal of Social Sciences, vol. 8, no,10, 2015.

[5] G. Jayanti, "Implementation of NHT cooperative learning model on teacher learning outcomes of grade V elementary school cluster Lt.Wisnu Depasar Utara," Journal of Mimbar Primary Teacher Education Ganesha, vol. 2, no,1, 2014.

[6] Paramita, "Application of cooperative learning model NHT assisted audio visual media to improve learning outcomes natural science," Journal of mimbar primary teacher education ganesha, vol. 4, no,1, 2016. Journal of Mimbar Primary Teacher Education Ganesha, vol. 4, no, 1, 2016.

[7] Sayun, "The effect of cooperative learning Model Numbered Head Together (NHT) and assessment form of mathematics learning achievement," Journal postgraduate of Ganesha Education, vol. 3, 2013.

[8] Pradnyani, "Effect of Numbered Head Together learning model on mathematics learning achievement viewed from habit of learning in elementary school,", , Journal postgraduate of Ganesha Education, vol. $3,2013$.

[9] Juniantari, "The Effect of cooperative learning model NHT multimedia assisted learning outcomes students class V elementary school social sciences cluster III district of gianyar," e-Journal Of Primary Teacher Education Ganesha, vol. 2, no, 1, 2014.

[10] Dewi, "The effect of cooperative learning model Numbered Head Together (NHT) aided by KIT natural science on creativity and student learning outcomes in science class IV elementary school," e-Journal postgraduate of Ganesha Education, vol. 3, 2013.

[11] Yudiastuti, "The effect of type Numbered Heads Together (NHT) concentrated learning model on students' grade students learning outcomes in Class V Gugus 1 Dalung district Kuta Utara," Journal of Mimbar Primary Teacher Education Ganesha, vol. 2, no, 1, 2014.

[12] Kompri, "Motivation of teacher and student perspective learning," Bandung: Remaja Rosdakarya, 2015, pp.237.

[13] Nurmala, "The influence of learning motivation and learning activity to accounting learning outcomes," Journal Ganesha Education, vol. 4, no,1, 2014.

[14] N.S. Lestari, "The influence of Problem Based Learning model and learning motivation on physics learning achievement for VII Junior high school students, Journal articles, 2011.

[15] Hamdu and Agustina, "The effect of students motivation on the achievement of science learning in primary school," Journal Educational Research, vol. 12, no,1, 2011. 